\title{
Assessment of Atherogenic Indices after treating with Sookshma Eladi Churnam in Hyperlipidaemia - A Case Study
}

\author{
Case Report
}

\section{Harinatha Chary B1*, Manu $\mathbf{R}^{2}$, Gnana Prasuna $\mathrm{S}^{3}$}

1. Ph.D. Scholar, 2. Professor, 3. Ph.D Scholar,

Department of Kayachikitsa, Parul Institute of Ayurved, Parul University, Vadodara.

\begin{abstract}
Background: Hyperlipidaemia is one of the most important conditions to cause atherosclerosis. Atherosclerosis is a major risk factor for coronary artery disease (CAD). CAD has become the epidemic of modern civilization in which Hyperlipidaemia predominantly contributes to its pathogenesis. There are certain atherogenic ratios that are strongly predictive of CAD. Three important atherogenic ratios are Atherogenic Index of Plasma (AIP), Castelli's Risk Index I \& II (CRI-I \&CRI-II). We studied the significance of these atherogenic ratios in a case study having hyperlipidaemia by giving Ayurvedic drug Sookshma eladi choornam. Methods: A 53-year-old patient presented with tiredness, shortness of breath on exertion, heaviness of the body parts for the past 4 months. Management was done on OPD based treatment. The patient was administered 3 grams of Sookshma eladi choornam orally with go ghrita as anupana. Result: There was a marked reduction in symptoms like tiredness, heaviness and shortness of breath with three months of treatment. The lipid values after three months of treatment and follow up of one month showed a marked reduction in TC(Total Cholesterol), TG(Triglyceride), LDL-C(Low density lipoprotein Cholesterol) and increase in HDL(High density lipoprotein - Cholesterol). Conclusion: Significant result was observed in both subjective symptoms and in objective parameters after administering Sookshma eladi choornam.
\end{abstract}

Key Words: Hyperlipidaemia, Atherosclerosis, Coronary artery disease, Atherogenic Index of Plasma, Castelli's Risk Index I \& II.

\section{Introduction}

One-third of deaths worldwide are due to Cardiovascular diseases. The risk is still being in an increased scenario in both developing and developed countries because of increasing risk factors like obesity, hyperlipidaemia, diabetes mellitus, poor physical activity and smoking (1). Among them hyperlipidaemia is the dominant risk factor and strong predictive indicator of Coronary artery disease (CAD ) (2).

According to Ayurveda the etiological factors like medhyanam chaatibhakshanam (excess intake of fatty food), varuni sevana (excess alcohol consumption), Avyayama (lack of physical exercise), Diwasawapna (day sleep) lead to accumulation of morbid medas or lipids contributing to hyperlipidaemias.

Hyperlipidaemia is a condition where there is elevated plasma concentration of lipids (total cholesterol (TC), triglyceride (TG) and their blood transporting lipoproteins namely Low density lipoproteins (LDL-Cholesterol), Very Low density

\section{* Corresponding Author:}

\section{Harinatha Chary B}

$\mathrm{PhD}$ scholar,

Department of Kayachikitsa,

Parul Institute of Ayurveda,

Parul University, Vadodara, Gujarat. India.

Email Id: drbnchary@gmail.com lipoproteins (VLDL-Cholesterol) and decreased plasma concentration of High density lipoproteins (HDLCholesterol). Hyperlipidemia is always considered being a risk factor for ischaemic heart disease (IHD) and peripheral vascular disease. (4)

It is an established fact that there is a strong association of CAD with high concentrations of LDL-C along with low levels of HDL-C. (5), (6)

Indeed high concentrations of $\mathrm{TG}$ also contribute to $\mathrm{CAD}$. The identification of high risk individuals can be done with different combinations of these lipid profile parameters like Atherogenic Index of Plasma (AIP), Castelli's Risk Index I (CRI-I) \& Castelli's Risk Index II (CRI-II). (7)

\section{Material and Methods}

This is a single case study. Before starting the treatment informed consent was taken from the patient in her own language.

\section{Case Study}

A 53 years old female patient presented with tiredness, shortness of breath on exertion, heaviness of the body parts and lack of enthusiasm for the past 4 months associated with occasional giddiness since last month at Kayachikitsa department OPD (OPD No: 3051.) of S.V. Ayurvedic College, TTD, Triupati, AP. on $11-01-2020$ 
History of present illness

Patient was normal before four months. Gradually she developed mild shortness of breath after walking for one kilometer. She was feeling tired even during rest. She was also experiencing heaviness of body parts and lack of enthusiasm. All these symptoms were of four months duration. Since last month she was having occasional giddiness especially in the morning time. Patient was at times experiencing excess sleep. She is neither diabetic nor hypertensive. So, patient visited our hospital.

\section{Personal History}

Diet: Mixed diet, Diet pattern: adhyasana, Bowel: Regular (1 or 2 times/day), Micturition : 5-6 times/day, Sleep: Normal or excess (occasional), Addictions: No addiction, Agni: Vishama, life style: Mostly sedentary, Rasa pradhana ahara: Madhura

\section{Occupational History:}

House wife

Socio-economic status \& Habitat:

Lower-middle class; Urban

\section{On Examination}

\section{Physical examination}

a. Built: Obese, b. Body weight $(\mathrm{kg}): 108$, c. height: $157 \mathrm{~cm}$ d. BMI: 43.8. e. Pulse: 92, f. B.P: $140 / 80 \mathrm{~mm}$ of $\mathrm{Hg}$. g. Respiratory rate: $20 / \mathrm{mt} \mathrm{h}$. CVS: S1, S2 heard. No murmur, i. Respiratory system: Normal, No added sounds

\section{Dasavidha pareeksha}

1. Prakruti:Kaphavata, 2. Vikruti:Kaphameda, 3. Sara:Madhyama, 4. Samhanana:Pravara 5. Pramana: Pravara, 6. Satmya: Madhyama, 7. Satva: Madhyama, 8.Ahara shakti:Madhyama, 9. Vy a y a ma shakti:Avara, 10. Vayah:Madhyama

\section{Investigations done:}

a. Lipid profile

Lipid profile (12.01.2020) showed TC - 274.2 $\mathrm{mg} / \mathrm{dl}$, TG - $356 \mathrm{mg} / \mathrm{dl}$, LDL-C - $175 \mathrm{mg} / \mathrm{dl}$ and HDLC $-28 \mathrm{mg} / \mathrm{dl}$.

b. Thyroid profile

Thyroid profile (12.01.2020) showed T3 - 1.24 ng/dl, T4- $9.63 \mathrm{ng} / \mathrm{dl}, \mathrm{TSH}-3.56 \mu \mathrm{IU} / \mathrm{ml}$.

\section{Diagnosis: Hyperlipidaemia}

\section{Therapeutic intervention}

She was adviced to take Sookshma eladi choornam (8) in a dose of 3 grams with goghrita as anupana dravya, twice, after morning breakfast and night after dinner for 3 months. After the completion of three months of study again lipid profile was done. Weight and BMI were also observed.

\section{Pathya-apathya:}

There was no specific diet schedule advised. The patient was asked to continue her normal routine regular diet.

\section{Results}

The results were drawn basing on the below reference values.

According to Adult Treatment Panel III (2001) [2] , plasma levels for $\mathrm{TC}<200 \mathrm{mg} / \mathrm{dL}$, for $\mathrm{TG}<150 \mathrm{mg} /$ $\mathrm{dL}$, for LDL-C $<130 \mathrm{mg} / \mathrm{dL}$, and for HDL-C $>40 \mathrm{mg} / \mathrm{dL}$ are considered as normal otherwise abnormal.

Atherogenic Index of Plasma (AIP) is calculated as $\log$ TG/HDL-C. If the values are from -0.3 to 0.1 , indicate low risk, 0.1 to 0.24 with medium risk and above 0.24 with high risk of Caronary vascular disease. Castelli's Risk Index (CRI-I) is calculated as TC/HDL-C. The values are below 3.5 are considered as ideal and above 5 considered as high risk for cardiovascular disease. Similarly Castelli's Risk Index (CRI-II) is calculated as LDL-C/HDL-C and the ideal range is below 2 and above 5 considered to be high risk for cardiovascular disease.

Subjective symptoms were graded from 0 to 4 .

\begin{tabular}{|c|c|c|c|}
\hline $\begin{array}{l}\text { Gra } \\
\text { ding }\end{array}$ & $\begin{array}{l}\text { Shortness } \\
\text { of breath } \\
\text { (SOB) }\end{array}$ & Tiredness & $\begin{array}{l}\text { Heaviness of body } \\
\text { parts }\end{array}$ \\
\hline 0 & $\begin{array}{l}\text { No SOB } \\
\text { after heavy } \\
\text { work }\end{array}$ & $\begin{array}{l}\text { With heavy } \\
\text { work for more } \\
\text { than } 1 \mathrm{hr}\end{array}$ & $\begin{array}{l}\text { Absence of } \\
\text { heaviness of the } \\
\text { body }\end{array}$ \\
\hline 1 & $\begin{array}{l}\text { SOB after } \\
\text { heavy } \\
\text { work }\end{array}$ & $\begin{array}{l}\text { With heavy } \\
\text { work for more } \\
\text { than } 30 \mathrm{~min}\end{array}$ & $\begin{array}{l}\text { Feeling of } \\
\text { heaviness of the } \\
\text { body after walking } \\
\text { for } 1 \mathrm{~min}\end{array}$ \\
\hline 2 & $\begin{array}{l}\text { SOB after } \\
\text { moderate } \\
\text { work }\end{array}$ & $\begin{array}{l}\text { With moderate } \\
\text { work for } 15 \\
\text { min }\end{array}$ & $\begin{array}{l}\text { Feeling of } \\
\text { heaviness after } \\
\text { walking for } 30 \mathrm{sec}\end{array}$ \\
\hline 3 & $\begin{array}{l}\text { SOB after } \\
\text { little work }\end{array}$ & $\begin{array}{l}\text { With mild } \\
\text { work for } 5 \text { min }\end{array}$ & $\begin{array}{l}\text { Feeling of } \\
\text { heaviness after } \\
\text { walking for } 15 \mathrm{sec}\end{array}$ \\
\hline 4 & $\begin{array}{l}\text { SOB at } \\
\text { rest }\end{array}$ & Even at rest & $\begin{array}{l}\text { Feeling of } \\
\text { heaviness even at } \\
\text { rest }\end{array}$ \\
\hline
\end{tabular}

Table no: 2: Assessment of lipid profile

\begin{tabular}{|c|c|c|c|}
\hline $\begin{array}{l}\text { Lipid } \\
\text { Parameters }\end{array}$ & $\begin{array}{c}\text { BT(mg/dl) } \\
(12.01 . \\
2020)\end{array}$ & $\begin{array}{c}\mathbf{A T}(\mathbf{m g} / \mathbf{d l}) \\
(13.04 . \\
2020)\end{array}$ & $\begin{array}{c}\mathbf{F U}(\mathbf{m g} / \mathbf{d l}) \\
(15.5 . \\
2020)\end{array}$ \\
\hline Total Cholesterol & 274.2 & 169 & 163 \\
\hline Triglycerides & 356 & 140 & 130 \\
\hline LDL Cholesterol & 175 & 102 & 110 \\
\hline HDL Cholesterol & 28 & 39 & 27 \\
\hline $\begin{array}{l}\text { VLDL } \\
\text { Cholesterol }\end{array}$ & 71.2 & 28 & 26 \\
\hline TC/HDL Ratio & 9.79 & 4.33 & 6.03 \\
\hline LDL-C/HDL-C & 6.25 & 2.61 & 4.07 \\
\hline
\end{tabular}

BT-Before treatment, AT- After treatment, FUFollow up

Graph no: 1

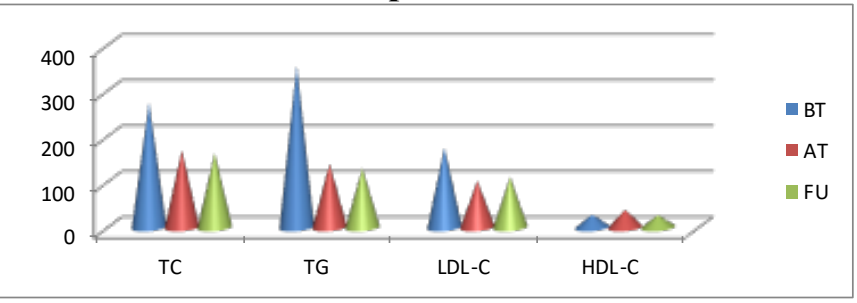


Table no: 3: Assessment of AIP, CRI-I \& CRI-II

\begin{tabular}{|c|c|c|c|}
\hline Parameter & BT & AT & FU \\
\hline AIP & 0.744 & 0.195 & 0.323 \\
\hline CRI- & 9.79 & 4.33 & 6.03 \\
\hline CRI-II & 6.25 & 2.61 & 4.07 \\
\hline
\end{tabular}

Graph no: 2

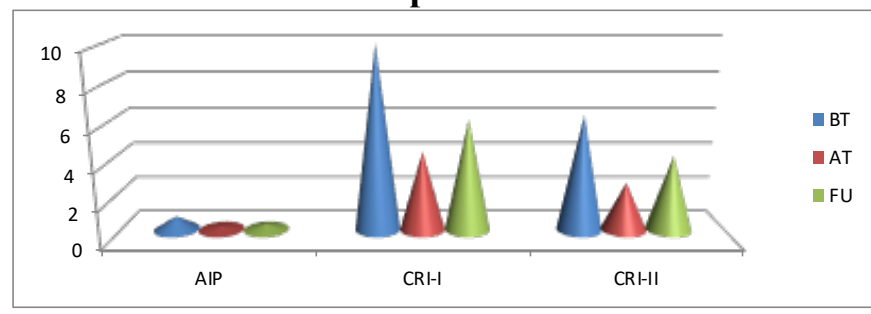

Table no: 4: Assessment of Weight \& BMI

\begin{tabular}{|l|l|l|l|}
\hline Parameter & BT & AT & FU \\
\hline Weight & 108 & 105 & 105 \\
\hline BMI & 43.8 & 42.6 & 42.6 \\
\hline
\end{tabular}

BMI - Body Mass Index

Graph no: 3

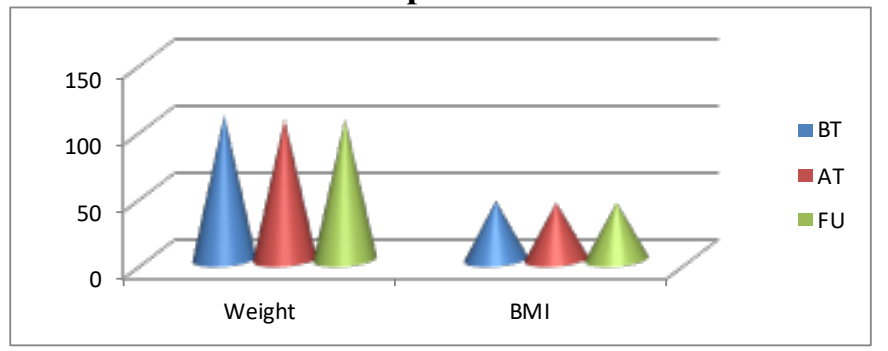

Table no: 5: Assessment of subjective and symptoms

\begin{tabular}{|l|c|c|c|}
\hline Parameter & BT & AT & FU \\
\hline Shortness of breath & 2 & 0 & 0 \\
\hline Tiredness & 2 & 0 & 0 \\
\hline Heaviness of body parts & 3 & 1 & 0 \\
\hline
\end{tabular}

Subjective symptoms graded \& assessed according to patient relief

\section{Graph no: 4}

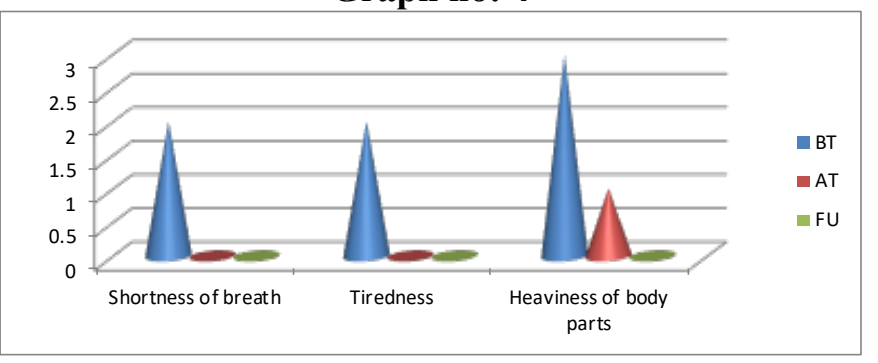

\section{Discussion}

Hyperlipidaemia refers to a condition where there is a presence of increased levels of lipoproteins in circulating blood. According to Ayurveda the pathogenesis of hyperlipidaemia is because of the hypo functioning of medodhatvagni along with vitiation of kapha dosha. The combination of morbid kapha and medas in srotas may cause dhamani pratichaya. In this condition accumulation of medas and kapha obstructs channels of circulation. Medus can be compared to the lipids in the body. Accumulation of medas along with kapha can be compared to the accumulation of fatty plaques in the arterial walls. Hence, this can be compared to atherosclerosis which is a major contributing factor for coronary artery disease. The etiological factors which increase the quantity of kapha and medas in the body lead to hyperlipidaemia. The patient is obese and her prakruti is Kaphavata. She indulged in adhyasana and used to take more madhurarasa ahara dravya. Her weight was $108 \mathrm{~kg}$. She had a habit of excess sleep during day time. All these etiological factors contributed to kapha-medo vruddi in the body. As a result, she developed symptoms of medovruddi lakshanas like swasa (shortness of breath), alasya (tiredness), anga gaurava (heaviness of body parts). Her lipid parameters were also increased. Many drugs are available in the modern system of medicine to counteract this problem, but the side effects concurring by them are forcing medical science to look for the best solution in alternative system of medicine. Ayurveda advocates a number of yogas or formulations which can reverse the pathology of dhamani pratichaya. One of them is Sookshma eladi choornam. After 3 months of treatment, there is a significant improvement in subjective and objective parameters.

\section{Probable mode of action of Sookshma eladi choornam}

The ingredients of Sookshma eladi choornam are Sookshma ela (Elettaria cardamomum (L.) Maton) and Pippali moola (Piper longum L.). These drugs are of Katu, laghu and Ushna in nature. Though sookshma ela is seeta veerya in nature its vipaka is Katu vipaka. Hence, both the drugs are kapha and medo haras. Goghrita is anupana of Sookshma eladi choornam. Goghrita multiply the qualities of ela and pippali moola as it is yogavahi in nature. Hence, Sooskhma eladi choornam is a unique drug with unique combination and highly effective in reversing the pathology caused by morbid kapha and meda. This might be the reason for regression or control of abnormal lipids. The AIP, CRI-I, CRI-II indices are also decreased significantly. Thus, there is a decrease in the chance of coronary vascular disease. The subjective symptoms like shortness of breath, tiredness, heaviness of body parts and giddiness were remarkably reduced. It also showed an effect on weight. The patient reduced her weight about $3 \mathrm{~kg}$ after the treatment. When follow up study was done after one month, there was a little elevation of lipid levels.

\section{Conclusion}

From this case study we can conclude that Sookshma eladi choornam is a very potent and effective drug in the management of Hyperlipidaemia. No adverse effect was noted and no aggravation of symptoms observed during the whole treatment. It had shown its sustained effect even after one month of follow up. The study with a larger sample would prove Sookshma eladi choornam as an effective remedy for hyperlipidaemia. 


\section{References}

1. Deaton C, Froelicher ES, Wu LH, Ho C, Shishani $\mathrm{K}$, Jaarsma T. The global burden of cardiovascular disease. Eur J Cardiovasc Nurs. 2011 Jul;10 Suppl 2:S5-13.

2. Parinita K. Study of serum lipid profile in individuals residing in and around Nalgonda. Int $J$ pharm Bio Sci. 2012;2:110-116.

3. Sharma R K and Vaidya Bhagvan Dash, Charaka Samhita vol II, English translation. published by Chaukhambha Sanskrit series office, Varanasi -1, Third edition 1994, Vimana sthana Chap.5, Verse no 16, page no. 178.

4. Goldberg DM. The Plasma Lipoprotein system. Clinical Biochemistry Reviews. 1981;2:341-353.
5. Castelli WP. Cholesterol and lipids in the risk of coronary artery disease-the Framingham Heart study. Can J Cardiol. 1988;4:5-10.

6. Igweh JC, Nwagha IU, Okaro JM. The Effects of Menopause on the Serum lipid profile of Normal Females of South East Nigeria. Nigerian Journal of Physiological Sciences. 2005;20(1-2):48-53.

7. Bhardwaj, J. Bhattacharjee, M.K Bhatnagar, Atherogenic index of plasma, Castelli risk index and Atherogenic coefficient-new parameters in assessing cardiovascular risk, JPBS |Volume 3| Issue 3|JUL-SEP|2013|359-364.

8. Siddhi Nandhan Mishra, Siddhiprada Hindi commentary, Bhaisajya Ratnavali of Kaviraj Govind Das Sen, Chowkamba Surabharati prakashan, Varanasi, edi: 2005, chap 33, verse 14, pg 667. 